\title{
The effect of storage conditions on the composition and functional properties of blended bulk tank milk
}

\author{
A. O’Connell, ${ }^{\dagger} \dagger$ A. L. Kelly, $\ddagger$ J. Tobin, $§$ P. L. Ruegg, $†$ and D. Gleeson*1 \\ ${ }^{*}$ Teagasc, Livestock Systems Research Department, Animal and Grassland Research and Innovation Centre, Moorepark, Fermoy, \\ Co. Cork, Ireland \\ †Department of Dairy Science, University of Wisconsin-Madison, Madison 53706 \\ ‡Department of Food and Nutritional Sciences, University College Cork, Cork, Ireland \\ $\S$ Food Chemistry and Technology Department, Teagasc Food Research Centre, Moorepark, Fermoy, Co. Cork, Ireland
}

\section{ABSTRACT}

The objective of this study was to investigate the effects of storage temperature and duration on the composition and functional properties of bulk tank milk when fresh milk was added to the bulk tank twice daily. The bulk tank milk temperature was set at each of 3 temperatures $\left(2,4\right.$, and $\left.6^{\circ} \mathrm{C}\right)$ in each of 3 tanks on 2 occasions during two 6 -wk periods. Period 1 was undertaken in August and September when all cows were in mid lactation, and period 2 was undertaken in October and November when all cows were in late lactation. Bulk tank milk stored at the 3 temperatures was sampled at 24-h intervals during storage periods of 0 to $96 \mathrm{~h}$. Compositional parameters were measured for all bulk tank milk samples, including gross composition and quantification of nitrogen compounds, casein fractions, free amino acids, and $\mathrm{Ca}$ and $\mathrm{P}$ contents. The somatic cell count, heat stability, titratable acidity, and rennetability of bulk tank milk samples were also assessed. Almost all parameters differed between mid and late lactation; however, the interaction between lactation, storage temperature, and storage duration was significant for only 3 parameters: protein content and concentrations of free cysteic acid and free glutamic acid. The interaction between storage temperature and storage time was not significant for any parameter measured, and temperature had no effect on any parameter except lysine: lysine content was higher at $6^{\circ} \mathrm{C}$ than at $2^{\circ} \mathrm{C}$. During $96 \mathrm{~h}$ of storage, the concentrations of some free amino acids (glutamic acid, lysine, and arginine) increased, which may indicate proteolytic activity during storage. Between 0 and $96 \mathrm{~h}$, minimal deterioration was observed in functional properties (rennet coagulation time, curd firmness, and heat stability), which was

Received April 13, 2016.

Accepted October 21, 2016.

${ }^{1}$ Corresponding author: david.gleeson@teagasc.ie most likely due to the dissociation of $\beta$-casein from the casein micelle, which can be reversed upon pasteurization. Thus, this study suggests that blended milk can be stored for up to $96 \mathrm{~h}$ at temperatures between $2^{\circ} \mathrm{C}$ and $6^{\circ} \mathrm{C}$ with little effect on its composition or functional properties.

Key words: raw milk, milk storage, storage temperature, proteolysis

\section{INTRODUCTION}

Due to ongoing expansion of the dairy industry in Ireland following the abolition of the milk quota system in the European Union in 2015, it is anticipated that on-farm storage of raw milk may be extended from $48 \mathrm{~h}$ to up to $96 \mathrm{~h}$ to improve logistical efficiency for milk processors. Current European Union legislation dictates that milk produced and stored on-farm must be cooled to at least $8^{\circ} \mathrm{C}$ when a daily milk collection regimen is in place, and to at least $6^{\circ} \mathrm{C}$ when collection is less frequent (Annex A, Directive 92/46; European Commission, 1992). However, many milk processors in Ireland request that milk be cooled to 2 to $4^{\circ} \mathrm{C}$ within 2 to $3 \mathrm{~h}$ after milking. There may be an economic incentive for farmers to store milk at higher temperatures (e.g., at $6^{\circ} \mathrm{C}$ compared with $2^{\circ} \mathrm{C}$ ) when milk is stored for longer durations on-farm, as milk cooling is a significant operational expenditure at the farm level (Upton et al., 2013). However, cooling milk to higher temperatures, in conjunction with longer on-farm storage intervals, may have implications for milk quality, with possible deleterious effects on milk functionality at milk processing facilities.

Milk processing as a generic term covers the typical unit operations and processes applied to milk in an integrated milk processing facility. Such processes can include thermal processing-HTST pasteurization and UHT or high temperature treatments. Separation technologies can include centrifugal separation, microfiltration, ultrafiltration, nanofiltration, and reverse 
osmosis, whereas concentration technologies include evaporation and spray drying.

Ireland's established reputation for efficient production of high-quality products has allowed the Irish dairy industry to become a major exporter of premium dairy products. The manufacture of such products requires the supply of the highest quality raw milk, highlighting the importance of on-farm milk storage conditions as a critical point in the dairy supply chain. On-farm storage of raw milk provides conditions suitable for the growth of microorganisms, with refrigerated conditions preferentially selecting for psychrotrophic bacteria, which can deleteriously affect the quality of raw milk through production of heat-stable proteinases and lipases (Sorhaug and Stepaniak, 1997; Haryani et al., 2003; Hantsis-Zacharov and Halpern, 2007).

Proteolysis can reduce the economic value of milk by negatively affecting its performance within milk processing facilities. In particular, the hydrolysis of casein can reduce cheese yield (Barbano et al., 1991; Klei et al., 1998). Lipolysis is the enzymatic conversion of lipids into free fatty acids (FFA) and partial glycerides. An increase in FFA in milk can result in undesirable off-flavors and altered functionality (Ma et al., 2000; Deeth, 2006), such as increased churning time during the production of butter (Deeth and Fitzgerald, 1995).

Due to enzymatic and microbial activity, both the microbial and functional quality of raw milk deteriorates with time. After storing raw milk obtained from 2 milkings at $4^{\circ} \mathrm{C}$ for $6 \mathrm{~d}$, Guinot-Thomas et al. (1995a) reported declines in $\mathrm{pH}$, casein nitrogen, $\beta-\mathrm{CN}$, and colloidal $\mathrm{Ca}$ and $\mathrm{P}$ contents, whereas levels of NPN and $\gamma$-CN increased. A reduction in the $\beta$-CN level of milk may also cause increased rennet coagulation time (RCT); de Moura Maciel et al. (2015) reported an increase in RCT after $24 \mathrm{~h}$ of storage of milk at $4^{\circ} \mathrm{C}$. The concentration of FFA in milk has been shown to increase during storage (Wiking et al., 2002). Muir et al. (1978) observed a temperature-dependent increase in concentrations of FFA in milk after $96 \mathrm{~h}$ of storage, with higher concentrations linked to milk stored at $8^{\circ} \mathrm{C}$ compared with $6^{\circ} \mathrm{C}$ or $4^{\circ} \mathrm{C}$.

Seasonal milk production is the dominant milk production system in Ireland (O'Connell et al., 2015), resulting in a large proportion of the national dairy cow population (1.127 million cows) approaching late lactation within the same period (during October and November). Due to adverse weather conditions and minimal grass growth during this period, cows are typically housed indoors. Consequently, cow's diets are altered from a pasture-based grazed grass to a grass silage system. During late lactation the total bacterial count (TBC) and SCC of milk also increase, often because of poorer environmental conditions and increased prevalence of subclinical mastitis within the herd (O'Connell et al., 2015). Alterations in diet, stage of lactation, and SCC can alter the composition of milk produced by cows. With a reduction in milk yield, the fat and protein contents of milk increase (Quinn et al., $2006)$; however, the $\beta-\mathrm{CN}$ and $\alpha_{\mathrm{S}^{-}} \mathrm{CN}$ contents of milk decrease and the $\gamma$-CN content increases because of higher plasmin activity during late lactation (Lucey, 1996; O'Brien et al., 2001). Late-lactation milk used for cheese production is associated with longer coagulation times and weaker gel structures, reducing its suitability for use (Lucey, 1996). Due to the changes in milk composition in late lactation, the milk produced during this period may be particularly susceptible to compositional and functional changes related to extended storage conditions of raw milk on farms due to less-frequent milk collections from the farm.

Milk with high SCC is often associated with elevated indigenous enzyme activity, which contributes to increased proteolysis and lipolysis during storage (Bastian and Brown, 1996; Deeth, 2006). The 2 most significant indigenous enzymes for milk spoilage are plasmin and lipoprotein lipase. Plasmin cleaves polypeptide chains after a lysine or, to a lesser extent, an arginine residue (Ueshima et al., 1996); $\alpha_{\mathrm{S1}^{-}}, \alpha_{\mathrm{S} 2^{-}}$, and $\beta-\mathrm{CN}$ are all susceptible to hydrolysis by plasmin (Andrews, 1983; Le Bars and Gripon, 1989; McSweeney et al., 1993a). Schroeder et al. (2008) showed that milk stored at lower temperatures $\left(2.2^{\circ} \mathrm{C}\right.$ compared with $\left.4.4^{\circ} \mathrm{C}\right)$ for $24 \mathrm{~h}$ resulted in less plasmin-induced proteolysis. However, Leitner et al. (2008) reported a $4 \%$ loss in curd yield from milk sourced from an uninfected cow ( $\mathrm{SCC}$ of 25,000 cells $/ \mathrm{mL}$ ) after $48 \mathrm{~h}$ of storage at $4^{\circ} \mathrm{C}$. This loss in yield was likely linked to continued casein proteolysis during cold storage, resulting in impairment of curd formation (Crudden et al., 2005a). Although plasmin activity in raw milk stored at low temperature $\left(5^{\circ} \mathrm{C}\right)$ is reduced due to autolysis and low temperature inhibition (Crudden et al., 2005b), the high thermal stability of the enzyme allows it to survive conventional pasteurization, which can limit the shelf life of resulting dairy products (Alichanidis et al., 1986). Lipoprotein lipase catalyzes the hydrolysis of ester bonds of triacylglycerols, resulting in the release of FFA, with the subsequent accumulation of short-chain FFA in milk and the development of off-flavors (Ma et al., 2000; Dickow et al., 2011). Lipoprotein lipase is relatively heat-sensitive and can be completely inactivated by pasteurization for $10 \mathrm{~s}$ at $85^{\circ} \mathrm{C}$ (Driessen, 1989).

On Irish farms, milk is stored in bulk milk tanks between milk collections, typically for $48 \mathrm{~h}$, and fresh milk is added to the bulk tank at each milking. Given 
the addition of fresh milk from each milking to the bulk tank between milk collections, only the milk harvested at the first milking is stored for the maximum duration. Thereafter, there is a stepwise reduction in the storage time of milk collected at each subsequent milking occasion. Thus, deterioration in milk quality is limited and likely to be lesser in magnitude compared with that considered in other studies in which the addition of fresh milk during the storage period was not studied (Guinot-Thomas et al., 1995a,b). Most of the current literature has documented laboratory-based experiments that aim to simulate on-farm storage conditions. However, no study has accounted for the sequential addition of fresh milk to stored milk within the on-farm storage period. With the possibility of large increases in on-farm milk storage periods (up to $96 \mathrm{~h}$ ), particularly after peak milk production (mid lactation), there is a need to establish the real-time effects of extended storage periods of raw milk on-farm, while also accounting for the effect of continued addition of fresh milk throughout the storage period.

Thus, the objective of this study was to investigate the effects of bulk tank storage temperature and storage time on the composition and functionality of bulk tank milk during mid and late lactation, when fresh milk was added twice daily throughout the storage period.

\section{MATERIALS AND METHODS}

Expanded details outlining the complete experimental design and milk sampling procedures can be found in the companion paper (O'Connell et al., 2016). Briefly, spring-calving dairy cows $(\mathrm{n}=280)$ were milked over two 6-wk periods: August 11 to September 26, 2014 (period 1; mean DIM of 172; mid lactation) and October 13 to November 21, 2014 (period 2; mean DIM of 235; late lactation). During period 1 and the first 4 wk of period 2, the cows were outdoors and consumed a diet of grass. During the remaining 2 wk of period 2, the cows were partially housed indoors during times of heavy rainfall in cubicles fitted with rubber mats that were bedded with lime, and consumed a diet consisting of approximately $50 \%$ grazed grass and $50 \%$ grass silage.

Three identical bulk milk tanks each with a capacity of 4,000 L (Swiftcool, Dairymaster, Causeway, Ireland) were used in this study. Each tank was set at 1 of 3 temperatures $\left(2,4\right.$, or $\left.6^{\circ} \mathrm{C}\right)$ on 2 occasions during mid lactation and on 2 occasions in late lactation, resulting in 6 test periods within each lactation period [3 treatments, 2 replicates of each temperature $(\mathrm{n}=3)$ at each tank] during which milk was stored for up to $96 \mathrm{~h}$. The 3 bulk tanks were set to cool milk to the different temperatures at the beginning of each test period. Valves in the milk-line were used to divide the milk flow in equal proportions to each of the 3 tanks. Equal volumes of fresh milk (approximately $300 \mathrm{~L}$ ) were collected in each tank at each milking over $96 \mathrm{~h}$. The milk passed through a plate cooler and was cooled to approximately $14.5^{\circ} \mathrm{C}$ before entering each tank, and the milk was subsequently cooled to the desired temperature within the tank. After each 96-h storage period, the milk was removed from each tank. Duplicate bulk tank milk samples for each test were taken from each tank immediately after the initial morning milking once milk was cooled to the desired temperature and subsequently at 24, 48, 72, and $96 \mathrm{~h}$, before morning milking, when there was milk from $2,4,6$, and 8 milkings, respectively, in each tank for analysis of composition and functional properties. To assess the quality of milk entering the bulk tanks at each milking, a milk sample was taken from the milk-line before the milk was diverted into each of the 3 tanks. A sample tap fitted to the milk-line, which recovered a constant stream of milk throughout milking, was used to collect this sample. The milk was collected in a sterile Durham flask that was surrounded by ice. These milk-line samples were analyzed for SCC and gross composition.

\section{SCC and Gross Composition}

Duplicate bulk tank milk samples and duplicate milk line samples were analyzed daily for fat, protein and lactose composition and SCC using a Milkoscan 203 (Foss Electric, Hillerød, Denmark).

Duplicate bulk storage tank milk samples were submitted for wet chemistry analysis of nitrogen fractions after storage for 0,48 and $96 \mathrm{~h}$. The percentage total protein, NPN, and noncasein nitrogen content of the milk samples were determined using the Kjeldahl method [methods 20-3 (IDF, 2004b), 20-4 (IDF, 2001), and 29-1 (IDF, 2004a), respectively] using a Tecator Digestor Auto and Kjeltec 8400 distiller (Foss Electric).

The protein composition of duplicate bulk storage tank milk samples was quantified daily $(0,24,48,72$, and $96 \mathrm{~h}$ ) by HPLC using the method described by Mounsey and O'Kennedy (2009). Briefly, $200 \mu \mathrm{L}$ of milk was diluted in $3,800 \mu \mathrm{L}$ of dissociating buffer (7 $M$ urea and $20 \mathrm{~m} M$ Bis-Tris propane, $\mathrm{pH}$ 7.5), to which $5 \mu \mathrm{L}$ of 2-mercaptoethanol was added, before filtering through a $0.22-\mu \mathrm{m}$ filter. Separation of the milk protein fractions was achieved in reverse-phase mode, using an Agilent Poroshell 300SB C18 column $(2.1 \times 75 \mathrm{~mm}$; Agilent Technologies, Santa Clara, CA). The HPLC equipment consisted of an Agilent 1200s with quaternary pump and multi-wavelength detector. Gradient elution and peak detection were performed according to the method of Mounsey and O'Kennedy (2009). 


\section{Free Amino Acid Analysis}

Bulk tank milk samples were analyzed daily in duplicate for free amino acid content. Briefly, samples were deproteinized by mixing equal volumes of $24 \%$ (wt/ vol) trichloroacetic acid and milk sample, followed by equilibration for $10 \mathrm{~min}$ before centrifugation at 14,400 $\times g$ for $10 \mathrm{~min}$. Supernatants were removed and diluted with $0.2 M$ sodium citrate buffer $(\mathrm{pH} 2.2)$, and then diluted 1 in 2 with internal standard norleucine. Amino acids were quantified using a Jeol JLC-500/V amino acid analyzer (Jeol UK Ltd., Garden City, UK) fitted with a Jeol $\mathrm{Na}^{+}$high-performance cation-exchange column.

\section{Mineral Analysis}

Bulk tank milk samples collected from each tank at 0,24 , and $48 \mathrm{~h}$ were frozen at $-20^{\circ} \mathrm{C}$ before analysis of $\mathrm{Ca}$ and $\mathrm{P}$ contents, which was completed within 6 wk of collection. Five grams of each milk sample was diluted with $5 \mathrm{~g}$ of $\mathrm{HNO}_{3}$ (69\%, Trace Select for Trace Analysis, Fluka Analytical, Sigma-Aldrich Ireland Ltd., Arklow, Co. Wicklow, Ireland) and $0.5 \mathrm{~g}$ of $\mathrm{HCl}(37 \%$, Fluka Analytical). Samples were digested at 1,600 W using a microwave digester (Marsxpress CEM Microwave Technology Ltd., Dublin, Ireland), and digested samples were diluted to $100 \mathrm{~mL}$ with Milli-Q water. One milliliter of the $100-\mathrm{mL}$ digest was diluted to 10 $\mathrm{mL}$ with $\mathrm{HNO}_{3}(5 \%$, Fluka Analytical) and samples were assessed for $\mathrm{Ca}$ and $\mathrm{P}$ contents by inductively coupled plasma mass spectroscopy using an Agilent ASX 500 series auto-sampler (Agilent Technologies). The software used was Mass Hunter software (version A. 01.02 patch 4; Agilent Technologies).

\section{Assessment of Functional Properties}

The thermal stability of bulk storage tank milk samples was measured daily in duplicate. The heat coagulation time (HCT) was determined following the method described by Davies and White (1966). Milk (2.5 mL) was added to glass test tubes, which were placed in a rocker and immersed in an oil bath containing mineral oil at a temperature of $140^{\circ} \mathrm{C}$ (the $\mathrm{pH}$ of milk samples was not adjusted). The HCT was recorded as the time between immersing the sample in the oil bath and the appearance of protein aggregates within the test tubes.

Titratable acidity was measured daily on all bulk tank milk samples by titrating milk samples to an endpoint of $\mathrm{pH} 8.3$ (Metrohm automatic titrator) using 0.1 $M \mathrm{NaOH}$ (VWR, Dublin, Ireland).

Rennet coagulation time (RCT) was measured in duplicate daily using a Formagraph instrument (Type
11700, Foss Electric). Ten milliliters of milk was heated to $35^{\circ} \mathrm{C}$ and chymosin (Chr. Hansen, Cork, Ireland; diluted 1:20 with deionized water) was added according to the following calculation: (\% protein in milk $\times$ 36)/3.5. The samples were then incubated at $35^{\circ} \mathrm{C}$ in the Formagraph and the coagulation properties monitored over a 30-min period.

The following parameters were obtained from the bifurcated displacement/time output signal: RCT (i.e., the time in seconds for the onset of gelation), curd firming rate $\left(\mathbf{k}_{\mathbf{2}}\right.$; time in seconds required for the bifurcated signal to reach a width of $20 \mathrm{~mm}$ ), and curd firmness $\left(\mathbf{a}_{\mathbf{3} 0}\right.$; width in millimeters of the signal at $\left.30 \mathrm{~min}\right)$.

\section{Statistical Analysis}

The study was conducted using a multiple Latin square design with repeated measures (sampling bulk tank milk every $24 \mathrm{~h}$ ) whereby each temperature (2, 4, and $\left.6^{\circ} \mathrm{C}\right)$ and each bulk tank $(\mathrm{n}=3)$ were included each week $(n=6)$ for each lactation period $(n=2)$. Each Latin square was repeated 4 times throughout both lactation periods. Least squares means for the main effects of storage time, temperature, and their interaction were calculated using the MIXED procedure in SAS version 9.3 (SAS Institute, 2011). Storage time was defined as the total number of hours each tank had been cooling since the first addition of milk. Tank within week was the experimental unit. Response variables included milk gross composition, N, casein, and AA concentrations, renneting and heat stability properties, $\mathrm{Ca}$ and $\mathrm{P}$ concentrations, $\mathrm{pH}$, and titratable acidity.

The following general mixed model was offered to all parameters:

$$
\begin{gathered}
\mathrm{Y}=\mu+\text { tank }+ \text { time }+ \text { temp }+ \text { week }+ \text { lact }+ \text { time } \\
\times \text { temp }+ \text { lact } \times \text { week }+ \text { time } \times \text { temp } \times \text { lact }+\mathrm{e},
\end{gathered}
$$

where $\mathrm{Y}=$ response variable; tank = fixed effect of each bulk tank (1 to 3 ); time = repeated effect of storage time $(0,24,48,72,96 \mathrm{~h})$; temp = fixed effect of storage temperature $\left(2,4\right.$, and $\left.6^{\circ} \mathrm{C}\right)$; week $=$ fixed effect of sampling period (1 to 6$)$; lact $=$ fixed effect of lactation period (mid or late); time $\times$ temp $=$ interaction between storage temperature and time; lact $\times$ week $=$ interaction between lactation period and week; time $\times$ temp $\times$ lact $=$ interaction between storage time, storage temperature, and lactation period; and e = residual component.

When the interaction between lactation period, storage time, and storage temperature was not significant for a particular parameter, the fixed effect of lactation period, the interaction between lactation period and 
Table 1. Composition and SCC of milk-line samples in mid and late lactation

\begin{tabular}{|c|c|c|c|c|c|c|c|c|c|}
\hline $\begin{array}{l}\text { Composition/ } \\
\text { lactation period }\end{array}$ & $\begin{array}{c}\text { No. of } \\
\text { samples }\end{array}$ & Mean \pm SD & Maximum & Minimum & \multicolumn{5}{|c|}{ Percentile } \\
\hline \multicolumn{10}{|l|}{ Protein (\%) } \\
\hline Late & 46 & $4.30 \pm 0.11^{\mathrm{a}}$ & 4.53 & 4.07 & 4.13 & 4.20 & 4.31 & 4.39 & 4.44 \\
\hline \multicolumn{10}{|l|}{ Fat $(\%)$} \\
\hline Mid & 42 & $4.97 \pm 0.86^{\mathrm{b}}$ & 6.54 & 3.32 & 3.84 & 4.17 & 5.08 & 5.71 & 5.90 \\
\hline \multicolumn{10}{|l|}{ Lactose (\%) } \\
\hline Mid & 42 & $4.57 \pm 0.11^{\mathrm{a}}$ & 4.77 & 4.38 & 4.43 & 4.47 & 4.58 & 4.66 & 4.69 \\
\hline Late & 46 & $4.49 \pm 0.08^{\mathrm{b}}$ & 4.59 & 4.17 & 4.39 & 4.48 & 4.52 & 4.54 & 4.58 \\
\hline \multicolumn{10}{|c|}{$\mathrm{SCC}\left(\times 10^{3}\right.$ cells $\left./ \mathrm{mL}\right)$} \\
\hline Mid & 40 & $260 \pm 110^{\mathrm{b}}$ & 573 & 121 & 141 & 184 & 240 & 315 & 420 \\
\hline Late & 46 & $323 \pm 154^{\mathrm{a}}$ & 782 & 136 & 176 & 214 & 288 & 366 & 604 \\
\hline
\end{tabular}

${ }^{\mathrm{a}, \mathrm{b}}$ Means between lactation periods within a composition parameter with different superscripts differ significantly $(P<0.05)$.

week, and the interaction between storage temperature and storage time were removed from the model. The fixed effect of sampling period (week) was then coded 1 to 12 rather than 1 to 6 .

The unstructured covariance structure was used in all models. Residual checks were made to ensure that the assumptions of the analysis model were met. Treatment means were compared using the Tukey test at a $5 \%$ error probability.

\section{RESULTS AND DISCUSSION}

In this study, we investigated the effect of storage conditions on the composition and functional properties of blended bulk tank milk. Although we did not investigate the effects of storage of final product performance, the parameters we measured are commonly used within the dairy industry to predict the suitability of milk for processing. Assessing key performance indicators, such as thermal stability, titratable acidity, and rennetability, among others, can identify milk that is suitable for processing and that will not affect product quality or process performance. The level of FFA in stored milk was not measured in this study due to daily time constraints, and the microbiology of the milk stored in this experiment is described in a companion paper (O'Connell et al., 2016).

The fat and protein contents of the milk-line samples (milk sampled at each milking before entry into each tank) were higher in late lactation than mid lactation (Table 1). In contrast, the lactose level of milk entering the tanks was greater in mid lactation than in late lactation. Daily milk yields decreased as cows entered late lactation and, because of reduced dilution by milk volume, the concentrations of protein and fat in milk were higher in late lactation compared with mid lactation. Similar trends have been described by
Guinee et al. (2007), who reported that the decrease in milk yield with advancing stage of lactation coincided with increases in total protein and casein levels, and a reduction in that of lactose. Within each week, the differences in percentage protein of milk added to the bulk tanks (i.e., the difference between the milk-line sample with the highest percentage protein and that with the lowest percentage protein within each week) ranged from 0.12 to $0.31 \%$ in mid lactation and from 0.20 to $0.40 \%$ in late lactation. Within each week, the differences in percentage fat of milk added to the bulk tanks ranged from 2.01 to $2.53 \%$ in mid lactation and from 0.95 to $1.86 \%$ in late lactation (data not shown).

The median SCC of milk entering the bulk tanks was 240,000 and 288,000 cells/mL in mid and late lactation, respectively. In each lactation period, more than $25 \%$ of samples had an SCC $>300,000$ cells $/ \mathrm{mL}$. It is well documented that bulk milk SCC increases toward the end of lactation (Berry et al., 2006; Hagnestam-Nielsen et al., 2009; O'Connell et al., 2015), which is related to increased prevalence of cows with chronic subclinical mastitis. Herds with higher bulk tank SCC $(>200,000$ cells $/ \mathrm{mL}$ ) tend to have greater prevalence of IMI (Fenlon et al., 1995; Barkema et al., 1998; Rodrigues et al., 2005), and thus the SCC of milk stored in this experiment indicates the presence of IMI within the herd.

\section{Lactation Period}

Lactation period significantly affected the protein content of bulk tank milk samples, with significantly higher contents observed in late lactation than in mid lactation (Table 2). The mean protein level in bulk tank milk increased from $3.65 \%$ in wk 1 (average DIM = 172 ) of the mid-lactation period to $4.29 \%$ in wk 4 (average DIM $=263$ ) of the late-lactation period, before decreasing to $4.17 \%$ in the final week of the experiment. 
The decrease in protein from wk 4 of the late-lactation period is likely due to the inclusion of silage in the diet at this time. Similar trends have been reported for seasonal variation in the protein content of an Irish spring-calving herd (Guinee et al., 2007) and reflect the effect of stage of lactation of cows on the casein and protein contents in milk (White and Davies, 1958; Kefford et al., 1995; Auldist et al., 1996). Similarly, the fat content of bulk tank milk was significantly higher during late lactation than mid lactation, as reported by O'Brien et al. (1999). This increase in fat content for milk produced during late lactation reflects dietary changes such as increased fiber content of grazed grass and physiological changes relating to stage of lactation (Phelan et al., 1982). Although statistically significant, minimal changes were seen in percentage lactose between mid- and late-lactation milk, at levels of 4.57 and $4.52 \%$, respectively.

Casein number, percentage casein, and concentration of each casein fraction increased in late lactation (Table 2). Interestingly, lactation period had a significant effect on whey protein fractions, with the level of $\beta$-LG-b increasing between mid and late lactation, whereas $\beta$-LG-a was not affected, a result that requires additional research to elucidate. There have been conflicting reports on the distribution of $\beta-\mathrm{CN}$ throughout lactation. Barry and Donnelly (1980) found that the level of $\beta-\mathrm{CN}$ declined in late lactation, whereas Ostersen et al. (1997) reported that $\beta-\mathrm{CN}$ increased throughout lactation. In the latter study, cows had a low SCC $(<200,000$ cells $/ \mathrm{mL})$ and were dried off before daily milk yield declined to $<10 \mathrm{~L}$, which the authors suggested might account for the difference in results. In this study, although $\beta$-CN levels were higher in late lactation, the weekly means for $\beta$-CN content in late lactation declined in the last 3 wk of the study, as cows approached the end of lactation. The $\beta-\mathrm{CN}$ content decreased from 13.72 to $9.05 \mathrm{~g} / \mathrm{L}$ between wk 1 and 6 within the late-lactation test period. Although the plasmin activity in bulk tank milk was not measured in this study, it is postulated that the greater SCC in latelactation milk compared with mid-lactation milk could lead to elevated plasmin activity in the milk stored and thus increased proteolysis (Bastian and Brown, 1996).

The curd firmness $\left(\mathrm{a}_{30}\right)$ of milk samples in late-lactation increased significantly compared with the values for mid-lactation milk (Table 2). Conversely, the curd aggregation rate $\left(\mathrm{k}_{20}\right)$ was higher for mid-lactation milk compared with late-lactation milk, whereas RCT was not affected by lactation period (Table 2). It is known that protein content is a confounding variable in terms of the curd firmness of rennet-induced milk gels (Guinee et al., 1997). Thus, as protein levels increased in late lactation, $\mathrm{a}_{30}$ is expected to increase. An improvement

Table 2. The effect of lactation period on the composition and functional properties of bulk tank milk samples

\begin{tabular}{|c|c|c|c|c|}
\hline Item & $\begin{array}{c}\text { Mid } \\
\text { lactation }\end{array}$ & $\begin{array}{c}\text { Late } \\
\text { lactation }\end{array}$ & SEM & $P$-value \\
\hline Fat $(\%)$ & 4.72 & 5.13 & 0.049 & $<0.0001$ \\
\hline Protein (\%) & 3.90 & 4.23 & 0.004 & $<0.0001$ \\
\hline Lactose (\%) & 4.57 & 4.52 & 0.004 & $<0.0001$ \\
\hline Noncasein nitrogen (\%) & 0.13 & 0.15 & 0.001 & $<0.0001$ \\
\hline Casein number $(\%)$ & 78.59 & 77.35 & 0.118 & $<0.0001$ \\
\hline NPN $(\%)$ & 0.036 & 0.044 & 0.001 & $<0.0001$ \\
\hline Casein $(\%)$ & 3.06 & 3.33 & 0.011 & $<0.0001$ \\
\hline Phosphorus (g/L) & 0.96 & 01.00 & 0.003 & $<0.0001$ \\
\hline Calcium $(\mathrm{g} / \mathrm{L})$ & 1.26 & 1.38 & 0.005 & $<0.0001$ \\
\hline Heat coagulation time $(\mathrm{s})$ & 836 & 678 & 9.0 & $<0.0001$ \\
\hline $\mathrm{pH}$ & 6.69 & 6.77 & 0.003 & $<0.0001$ \\
\hline Rennet coagulation time (s) & 1,405 & 1,367 & 26 & 0.3251 \\
\hline Curd firming rate $\left(\mathrm{k}_{20} ; \mathrm{s}\right)$ & 472 & 367 & 16 & 0.0002 \\
\hline Curd firmness $\left(\mathrm{a}_{30} ; \mathrm{mm}\right)$ & 19.39 & 22.18 & 0.680 & 0.0088 \\
\hline Cysteic acid $(\mu \mathrm{g} / \mathrm{mL})$ & 13.71 & 9.30 & 0.23 & $<0.0001$ \\
\hline Glutamic acid $(\mu \mathrm{g} / \mathrm{mL})$ & 25.84 & 12.88 & 0.290 & $<0.0001$ \\
\hline Histidine $(\mu \mathrm{g} / \mathrm{mL})$ & 4.02 & 2.60 & 0.062 & $<0.0001$ \\
\hline Lysine $(\mu \mathrm{g} / \mathrm{mL})$ & 2.47 & 2.24 & 0.047 & 0.0026 \\
\hline Glycine $(\mu \mathrm{g} / \mathrm{mL})$ & 4.83 & 2.98 & 0.083 & $<0.0001$ \\
\hline Cysteine $(\mu \mathrm{g} / \mathrm{mL})$ & 7.73 & 5.68 & 0.158 & $<0.0001$ \\
\hline Arginine $(\mu \mathrm{g} / \mathrm{mL})$ & 2.97 & 2.50 & 0.065 & $<0.0001$ \\
\hline$\kappa-\mathrm{CN}(\mathrm{g} / \mathrm{L})$ & 4.17 & 4.92 & 0.055 & $<0.0001$ \\
\hline$\alpha_{S_{2}-} \mathrm{CN}(\mathrm{g} / \mathrm{L})$ & 3.23 & 3.28 & 0.032 & 0.2774 \\
\hline$\alpha_{\mathrm{S}^{-}}-\mathrm{CN}(\mathrm{g} / \mathrm{L})$ & 12.14 & 13.40 & 0.159 & $<0.0001$ \\
\hline$\beta-\mathrm{CN}(\mathrm{g} / \mathrm{L})$ & 9.82 & 11.45 & 0.116 & $<0.0001$ \\
\hline$\alpha-\mathrm{LA}(\mathrm{g} / \mathrm{L})$ & 0.90 & 0.87 & 0.018 & 0.1766 \\
\hline$\beta-\mathrm{LG}-\mathrm{a}(\mathrm{g} / \mathrm{L})$ & 3.11 & 3.27 & 0.088 & 0.1989 \\
\hline$\beta-\mathrm{LG}-\mathrm{b}(\mathrm{g} / \mathrm{L})$ & 1.90 & 2.58 & 0.313 & $<0.0001$ \\
\hline
\end{tabular}


in $\mathrm{k}_{20}$ was also observed by O'Brien et al. (1999), when milk from spring-calving cows was compared at $164\left(\mathrm{k}_{20}\right.$ $=11.8 \mathrm{~min})$ and $234 \mathrm{DIM}\left(\mathrm{k}_{20}=8.2 \mathrm{~min}\right)$. The greater concentration of $\mathrm{Ca}$ in late-lactation milk agrees with the observations of Auldist et al. (1996) and Ostersen et al. (1997) and may contribute to the increased curd firmness observed compared with mid-lactation milk (Guinee et al., 1997).

The HCT of milk samples was greater in mid lactation than in late lactation (Table 2), in agreement with the results of Kelly et al. (1982). The differences in heat stability between mid- and late-lactation milk reflects the challenges typically encountered in dairy processing facilities relative to thermal processing and concentration of late-lactation milk. Milk produced during late lactation, or when cows have mastitis, has a higher plasmin activity (Lucey, 1996; O'Mahony and Fox, 2013), promoting hydrolysis of casein, which may contribute to reduced thermal stability (Crudden et al., 2005a). Observed differences in thermal stability between mid- and late-lactation milk are most likely due to seasonal influences, such as changes in diet, coupled with stage of lactation. Variations in the natural level of urea in milk because of changes to the cows' diet (from grass to grass silage and supplements) appear to be a major factor influencing thermal stability (Kelly et al., 1982).

The concentration of free amino acids in bulk tank milk (cysteic acid, glutamic acid, histidine, lysine, glycine, cysteine and arginine) decreased $(P<0.01)$ between mid and late lactation (Table 2). Davis et al. (1994) reported similar changes in amino acid concentrations between mid and late lactation; however, in contrast to the results reported here, those authors reported increased concentrations of lysine in latelactation milk compared with mid-lactation milk.

\section{Interaction Between Lactation Period and Storage Temperature and Duration}

As demonstrated in this study, stage of lactation affects milk quality at both a gross nutritional level and a functional level. Given the seasonal nature of Irish milk production, this study included the interaction between lactation period, storage temperature, and storage duration at farm level to assess whether stage of lactation would cause different outcomes during storage on the parameters studied. The interaction between lactation period, storage temperature, and storage duration was only significant for protein content $(P<0.001$; Figure 1$)$, cysteic acid content $(P=0.03$; Figure 2$)$, and glutamic acid content $(P=0.047$; Figure 3$)$ in bulk tank milk. However, the interactions observed mainly reflect large differences relative to stage of lactation, with lesser effects observed within each discreet lactation period. For example, the range of values for protein content was between 3.86 and $3.92 \%$ and between 4.18 and $4.27 \%$ in mid and late lactation, respectively. However, smaller differences were seen in mid lactation where the protein content of bulk tank milk stored at $2^{\circ} \mathrm{C}$ and $4^{\circ} \mathrm{C}$ decreased between 72 and $96 \mathrm{~h}$ from 3.91 to $3.88 \%(P=0.0027)$ and from 3.91 to $3.88 \%(P=$ $0.0373)$, respectively; however, the industrial relevance of this difference is questionable. Similarly, no significant changes in cysteic acid contents were observed within each lactation period.

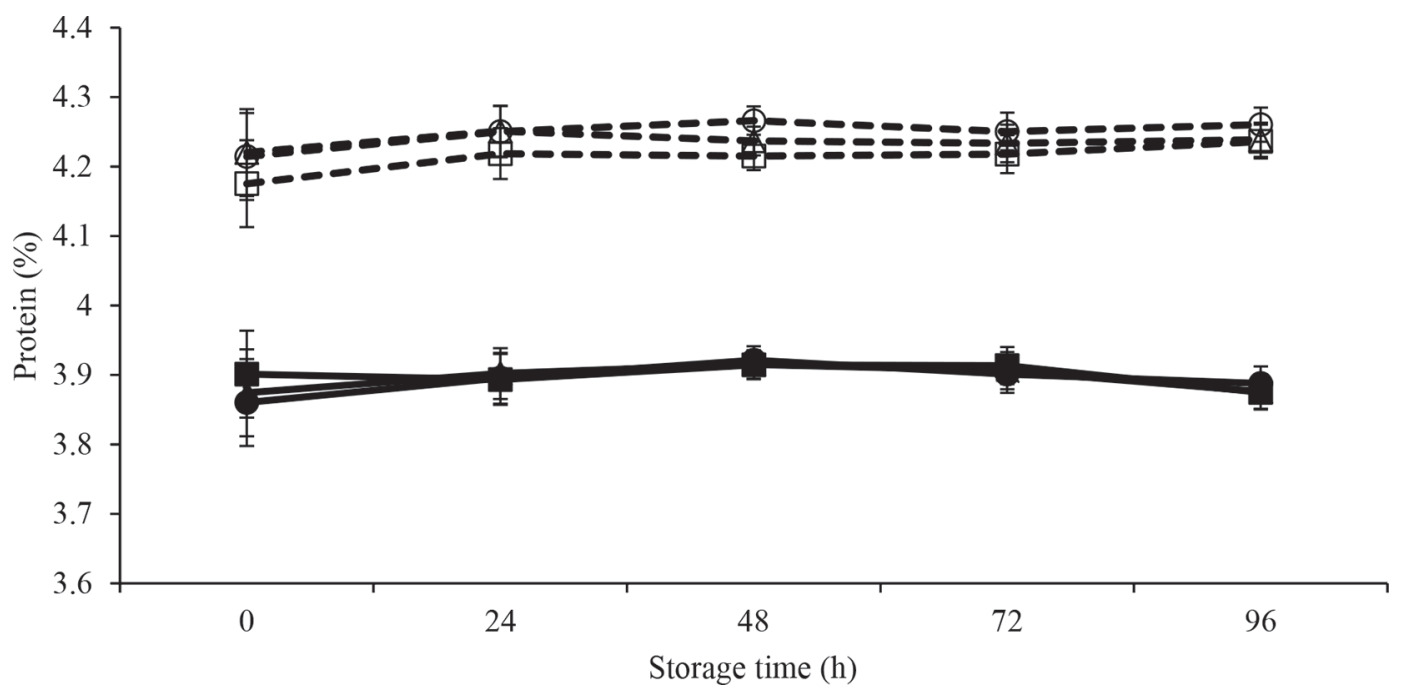

Figure 1. The effect of storage temperature $\left(2^{\circ} \mathrm{C}: \mathbf{\square} ; 4^{\circ} \mathrm{C}: \mathbf{\Delta} ; 6^{\circ} \mathrm{C}: \bullet\right)$ and duration on the protein concentration of bulk tank milk in mid lactation (solid lines and symbols) and late lactation (dashed lines and open symbols). Each bar represents the $95 \%$ CI for that mean. 


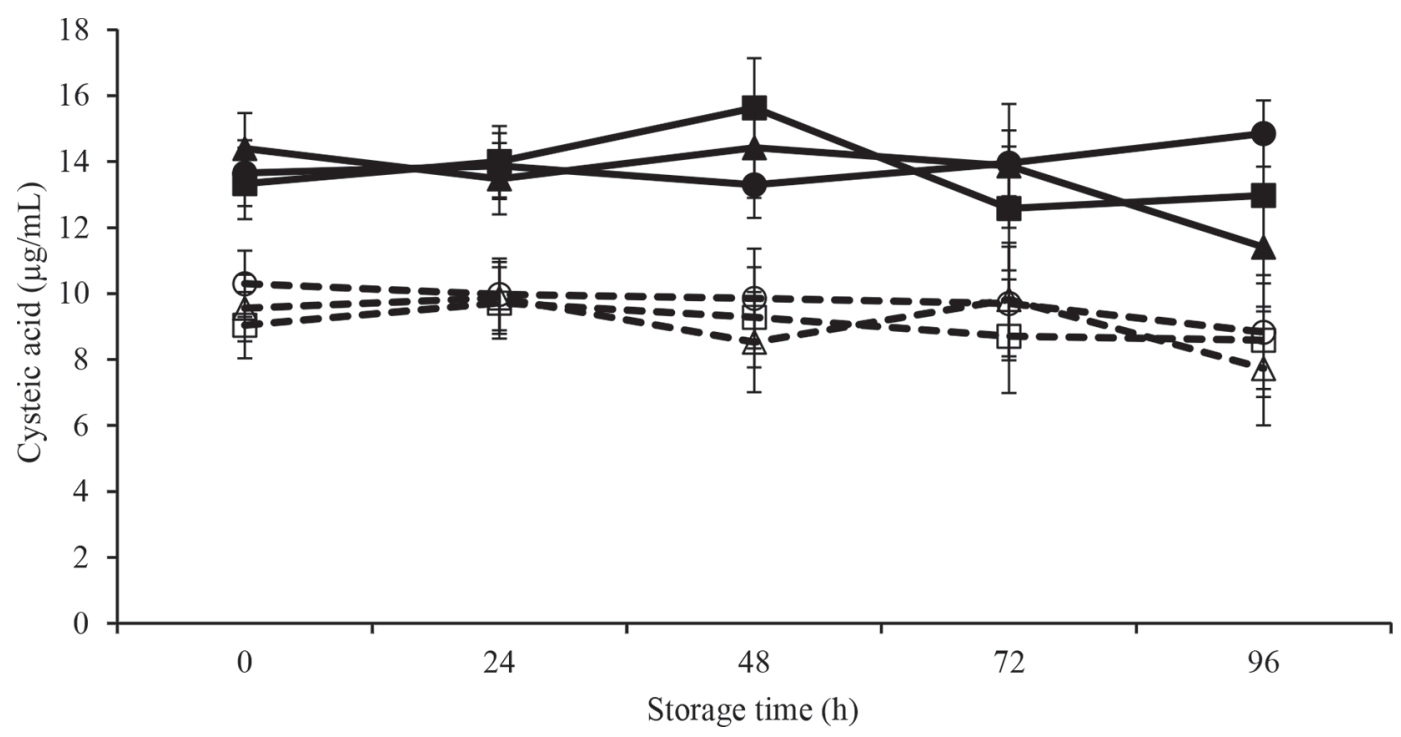

Figure 2. The effect of storage temperature $\left(2^{\circ} \mathrm{C}: \mathbf{\square} ; 4^{\circ} \mathrm{C}: \boldsymbol{\Delta} ; 6^{\circ} \mathrm{C}: \bullet\right)$ and duration on the concentration of cysteic acid in bulk tank milk in mid lactation (solid lines and symbols) and late lactation (dashed lines and open symbols). Each bar represents the $95 \%$ CI for that mean.

The amount of glutamic acid in bulk tank milk was greater in mid lactation than in late lactation (Figure $3)$. Between 0 and $24 \mathrm{~h}$, the glutamic acid content of milk increased from 22.04 to $26.18 \mathrm{~g} / \mathrm{L}$ when midlactation milk was stored at $6^{\circ} \mathrm{C}(P=0.011)$. In late lactation, the glutamic acid content of milk increased significantly $(P<0.05)$ between 0 and $24 \mathrm{~h}$ when stored at $2^{\circ} \mathrm{C}(10.50-14.18 \mathrm{~g} / \mathrm{L}), 4^{\circ} \mathrm{C}(10.02-14.61 \mathrm{~g} / \mathrm{L})$, and $6^{\circ} \mathrm{C}(10.76-14.91 \mathrm{~g} / \mathrm{L})$. The detection of changes in the free amino acid content of dairy products has previously been used as an indicator of proteolysis (McSweeney et al., 1993b; Doolan et al., 2014). Mc-
Sweeney et al. (1993b) postulated that an increase in free glutamic acid concentration in raw milk cheese compared with pasteurized milk cheese was linked to higher levels of proteolysis in raw milk cheese, resulting from greater peptidase activity from both indigenous and endogenous sources. Because glutamic acid is the most abundant free amino acid in bovine milk (Rassin et al., 1978; Lindmark-Månsson et al., 2003), it is perhaps not surprising that changes in glutamic acid were most apparent in this study, compared with other free amino acids, possibly indicative of proteolytic activity during storage.

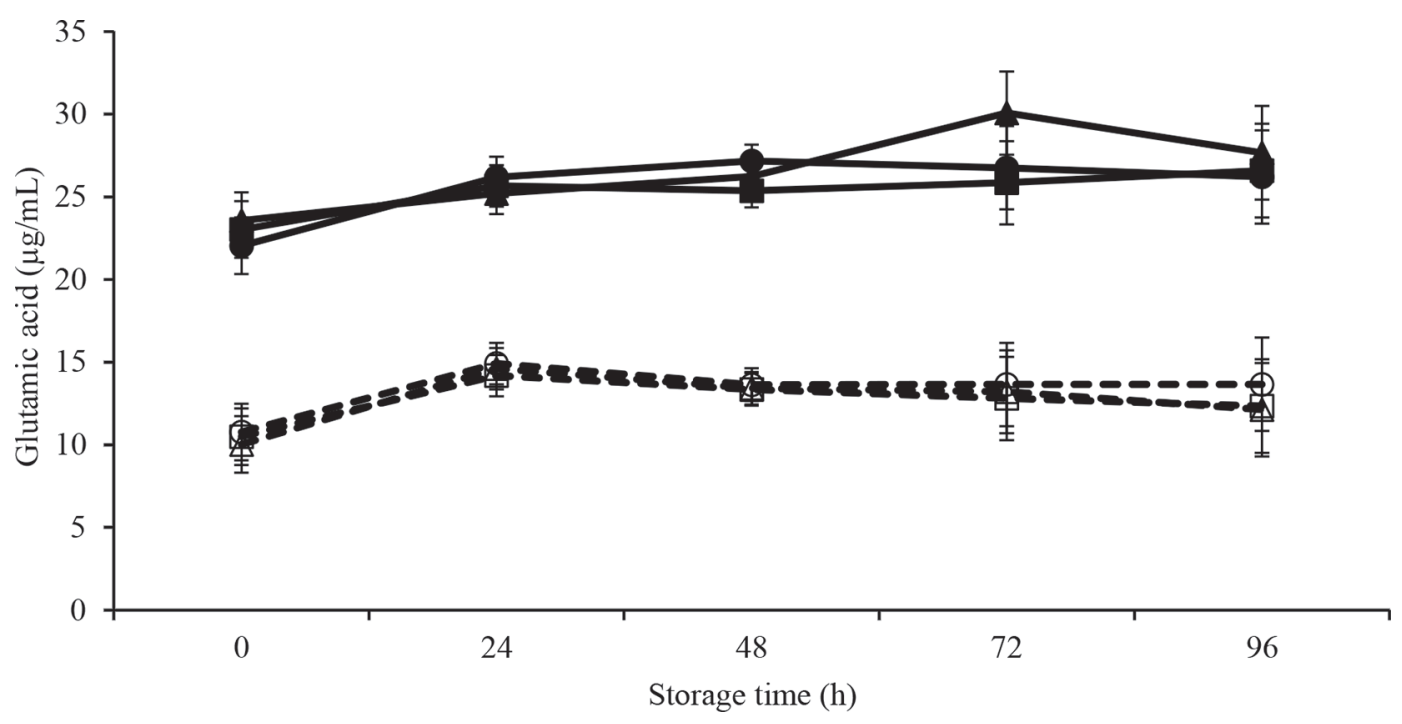

Figure 3. The effect of storage temperature $\left(2^{\circ} \mathrm{C}: \mathbf{\square} ; 4^{\circ} \mathrm{C}: \mathbf{\Delta} ; 6^{\circ} \mathrm{C}:-\right)$ and duration on the concentration of glutamic acid in bulk tank milk in mid lactation (solid lines and symbols) and late lactation (dashed lines and open symbols). Each bar represents the $95 \%$ CI for that mean. 


\section{Effect of Storage Temperature and Duration on the Composition of Bulk Tank Milk}

Because of the sequential addition of milk throughout storage, only milk from the first milking was stored for the full $96 \mathrm{~h}$. Thus, storage time was reduced for milk added at subsequent milkings throughout storage. This addition of fresh milk throughout storage in the current study is different from other studies that have investigated the effect of storage conditions on composition (Guinot-Thomas et al., 1995a,b; O'Brien et al., 1999). Thus, unlike other studies, the significance of both indigenous and endogenous enzymatic activity in milk may not be detected in this study due to the addition of fresh milk throughout storage. The addition of milk with varying composition and bacterial quality is also likely to limit detection of changes in milk quality due to storage. As indicated earlier, the composition of milk-line samples differed in each lactation period and values varied within week. However, as outlined in the companion paper, O'Connell et al. (2016), even though the TBC of milk entering the tanks from each milking were numerically different, $75 \%$ of samples had TBC $\leq 4,800 \mathrm{cfu} / \mathrm{mL}$, indicating that the bacterial count of the milk added was consistent. Despite these challenges, this study best reflects milk storage conditions experienced on commercial dairy farms. Moreover, the findings from this study can be used to extrapolate guidelines on the expected deterioration of milk composition during storage for milk processors and farmers alike.

We detected no effect of temperature or interaction between temperature and time on the percentage of fat and lactose in bulk tank milk (Table 3). The concentration of fat in milk increased between 0 and $24 \mathrm{~h}(P<$ $0.0001)$ of storage and remained unchanged thereafter (Table 4). Milk sampled at $0 \mathrm{~h}$ contained milk from the first morning milking of the trial period. Thereafter, milk sampled was a combination of milk obtained from morning and evening milkings. Because of the milking interval, cows produced more milk at the morning milking than the evening milking and thus, due to dilution, the fat content of milk was typically lower in milk collected from the morning milking than the evening milking (Walstra et al., 1999). This would account for the lower fat content of milk observed at $0 \mathrm{~h}$, which was not observed at any other sampling point.

In the current study, we detected no main effect of temperature on casein content in bulk tank milk; however, over time, the casein content of bulk tank milk increased from 3.19 to $3.22 \%$ between 0 and $48 \mathrm{~h}$ and then decreased to $3.18 \%$ between 48 and $96 \mathrm{~h}$ (Table $2)$. A reduction in casein content, often due to prote- olysis, was not observed in this study, and any changes in percentage casein due to proteolysis that may have occurred during storage are likely to be masked by the addition of fresh milk throughout the storage period. Significant proteolytic activity was seen in milk stored at $4^{\circ} \mathrm{C}$ after $6 \mathrm{~d}$ of storage by Guinot-Thomas et al. (1995a) when the psychrotrophic count increased from $10^{3} \mathrm{cfu} / \mathrm{mL}(\mathrm{d} 0)$ to $10^{6}$ to $10^{7} \mathrm{cfu} / \mathrm{mL}(\mathrm{d} 6)$. In the current study, the psychrotrophic count did not exceed $10^{5}$ cfu/mL (O'Connell et al., 2016), which may account for the difference in the results reported herein.

Similar to the findings of Guinot-Thomas et al. (1995a), we found no difference in the $\mathrm{P}$ or Ca concentrations of milk between 0 and $96 \mathrm{~h}$ when stored at 2 , 4 , or $6^{\circ} \mathrm{C}$; however, the partition of salts between the soluble and colloidal phases was not investigated.

The $\beta$-CN concentrations of milk were greater at $48 \mathrm{~h}$ than at $0 \mathrm{~h}(P=0.038$; Table 4$)$. Likewise, the concentrations of $\beta$-CN were greater in milk stored at 48 and $72 \mathrm{~h}$ compared with milk stored at $24 \mathrm{~h}(P=0.008$ and $P=0.034$, respectively; Table 4$)$. The increase in $\beta-\mathrm{CN}$ content throughout storage is most likely due to the addition of fresh milk throughout storage. We observed no effect of temperature on the total levels of $\beta-\mathrm{CN}$ in bulk tank milk; however, the effect of temperature on $\beta-\mathrm{CN}$ depletion from the casein micelle was not investigated. Decreases in $\kappa-\mathrm{CN}$ and $\beta-\mathrm{CN}$ contents of raw milk were observed by Guinot-Thomas et al. (1995a) between 96 and $144 \mathrm{~h}$ of storage at $4^{\circ} \mathrm{C}$. Coincidentally, this reduction was only observed as psychrotrophic bacterial counts exceeded $10^{6}$ to $10^{7} \mathrm{cfu} / \mathrm{mL}$, highlighting the importance of microbial growth relative to protein quality during storage.

The levels of arginine in bulk tank milk increased between 0 and $24 \mathrm{~h}(P<0.0001)$ and remained similar thereafter (Table 4). These findings are in contrast to those of Gandolfi et al. (1992), who measured contents of alanine, aspartic acid, and glutamic acid of milk before and after storage of raw milk samples $(n=2)$ at $4^{\circ} \mathrm{C}$ for $7 \mathrm{~d}$, and reported that D-alanine was the only amino acid to increase during storage, again attributed to growth of psychrotrophic bacteria during storage. As outlined in the companion paper (O'Connell et al., 2016), we detected limited growth of bacteria during storage in this study, which may account for the limited changes in amino acid concentrations observed. The levels of lysine increased between 0 and $96 \mathrm{~h}(P=0.0001)$ and as storage temperature increased from $2^{\circ} \mathrm{C}$ to $6^{\circ} \mathrm{C}$ $(P<0.05)$. Levels of lysine tended $(P=0.11)$ to be greater in milk stored at $6^{\circ} \mathrm{C}$ for periods greater than 48 $\mathrm{h}$ compared with milk stored at 2 or $4^{\circ} \mathrm{C}$ (Table 5). The slight increase in levels of total bacteria and psychrotrophic bacteria as storage temperature and duration 
Table 3. The significance of the main effects of storage time, temperature, and their interaction on the composition and functional properties of bulk tank milk samples

\begin{tabular}{|c|c|c|c|}
\hline \multirow[b]{2}{*}{ Item } & \multicolumn{3}{|c|}{$P$-value } \\
\hline & Time $^{1}$ & Temperature $^{2}$ & Time $\times$ Temperature \\
\hline Fat $(\%)$ & $<0.01$ & 0.44 & 0.43 \\
\hline Protein (\%) & $<0.01$ & 0.13 & 0.45 \\
\hline Lactose (\%) & $<0.01$ & 0.72 & 0.99 \\
\hline Noncasein nitrogen (\%) & 0.74 & 0.10 & 0.67 \\
\hline Casein number (\%) & 0.22 & 0.21 & 0.73 \\
\hline NPN $(\%)$ & 0.16 & 0.80 & 0.83 \\
\hline Casein $(\%)$ & 0.02 & 0.63 & 0.96 \\
\hline Phosphorus (g/L) & 0.57 & 0.43 & 0.70 \\
\hline Calcium $(\mathrm{g} / \mathrm{L})$ & 0.54 & 0.23 & 0.68 \\
\hline Heat coagulation time $(\mathrm{s})$ & $<0.01$ & 0.84 & 0.92 \\
\hline $\mathrm{pH}$ & 0.03 & 0.83 & 0.78 \\
\hline Rennet coagulation time $(\mathrm{s})$ & $<0.01$ & 0.97 & 0.36 \\
\hline Rate of curd aggregation (s) & 0.02 & 0.92 & 0.71 \\
\hline Curd firmness (mm) & $<0.01$ & 0.36 & 0.62 \\
\hline Titratable acidity $(\mathrm{mL})$ & 0.08 & 0.35 & 0.64 \\
\hline Cysteic acid $(\mu \mathrm{g} / \mathrm{mL})$ & 0.02 & 0.40 & 0.05 \\
\hline Glutamic acid $(\mu \mathrm{g} / \mathrm{mL})$ & $<0.01$ & 0.41 & 0.35 \\
\hline Histidine $(\mu \mathrm{g} / \mathrm{mL})$ & 0.21 & 0.80 & 0.26 \\
\hline Lysine $(\mu \mathrm{g} / \mathrm{mL})$ & $<0.01$ & $<0.01$ & 0.11 \\
\hline Glycine $(\mu \mathrm{g} / \mathrm{mL})$ & 0.39 & 0.32 & 0.65 \\
\hline Cysteine $(\mu \mathrm{g} / \mathrm{mL})$ & 0.13 & 0.47 & 0.33 \\
\hline Arginine $(\mu \mathrm{g} / \mathrm{mL})$ & $<0.01$ & 0.39 & 0.26 \\
\hline$\kappa-\mathrm{CN}(\mathrm{g} / \mathrm{L})$ & 0.03 & 0.40 & 0.99 \\
\hline$\alpha_{\mathrm{S} 2}-\mathrm{CN}(\mathrm{g} / \mathrm{L})$ & 0.06 & 0.81 & 0.89 \\
\hline$\alpha_{\mathrm{S}^{-}}-\mathrm{CN}(\mathrm{g} / \mathrm{L})$ & 0.05 & 0.85 & 0.83 \\
\hline$\beta-\mathrm{CN}(\mathrm{g} / \mathrm{L})$ & 0.01 & 0.46 & 0.93 \\
\hline$\alpha-\mathrm{LA}(\mathrm{g} / \mathrm{L})$ & 0.22 & 0.50 & 0.91 \\
\hline$\beta-\mathrm{LG}-\mathrm{a}(\mathrm{g} / \mathrm{L})$ & 0.07 & 0.63 & 0.85 \\
\hline$\beta-\mathrm{LG}-\mathrm{b}(\mathrm{g} / \mathrm{L})$ & 0.01 & 0.91 & 0.93 \\
\hline
\end{tabular}

${ }^{1}$ Milk was stored for $96 \mathrm{~h}$ and sampled every $24 \mathrm{~h}$. Fresh milk was added to the tank at each milking throughout storage.

${ }^{2}$ Milk was stored at 2,4 , or $6^{\circ} \mathrm{C}$ throughout storage.

increased (O'Connell et al., 2016) and the subsequent production of microbial proteases in milk throughout storage may have contributed to increased proteolytic activity, which may account for the increased concentration of particular amino acids, as observed by Albert et al. (2009).

\section{Assessment of Functional Properties}

The HCT of bulk tank milk was affected by storage time $(P<0.01$; Table 3$)$ but not by temperature or the interaction between temperature and time. The $\mathrm{HCT}$ decreased between 0 and $72 \mathrm{~h}$ and then increased

Table 4. The effect of storage time on the composition and functional properties of bulk tank milk ${ }^{1}$

\begin{tabular}{|c|c|c|c|c|c|c|}
\hline \multirow[b]{2}{*}{ Item } & \multicolumn{5}{|c|}{ Storage time $(\mathrm{h})$} & \multirow[b]{2}{*}{$P$-value } \\
\hline & 0 & 24 & 48 & 72 & 96 & \\
\hline Fat $(\%)$ & $4.52 \pm 0.07^{\mathrm{b}}$ & $5.00 \pm 0.05^{\mathrm{a}}$ & $5.02 \pm 0.031^{\mathrm{a}}$ & $5.02 \pm 0.03^{\mathrm{a}}$ & $5.06 \pm 0.02^{\mathrm{a}}$ & $<0.01$ \\
\hline Lactose $(\%)$ & $4.53 \pm 0.010^{\mathrm{ab}}$ & $4.53 \pm 0.007^{\mathrm{b}}$ & $4.55 \pm 0.004^{\mathrm{ab}}$ & $4.55 \pm 0.004^{\mathrm{b}}$ & $4.56 \pm 0.002^{\mathrm{a}}$ & $<0.05$ \\
\hline Casein $(\%)$ & $3.19 \pm 0.016^{\mathrm{ab}}$ & & $3.22 \pm 0.008^{\mathrm{a}}$ & & $3.18 \pm 0.001^{\mathrm{b}}$ & $<0.05$ \\
\hline Heat coagulation time $(\mathrm{s})$ & $803 \pm 26^{\mathrm{a}}$ & $803 \pm 9^{\mathrm{a}}$ & $739 \pm 8^{\mathrm{ac}}$ & $704 \pm 7^{\mathrm{bc}}$ & $736 \pm 7^{\mathrm{bc}}$ & $<0.05$ \\
\hline $\mathrm{pH}$ & $6.71 \pm 0.01^{\mathrm{b}}$ & $6.74 \pm 0.01^{\mathrm{ac}}$ & $6.74 \pm 0.01^{\mathrm{bc}}$ & $6.73 \pm 0.01^{\mathrm{bc}}$ & $6.72 \pm 0.01^{\mathrm{bc}}$ & $<0.05$ \\
\hline Rennet coagulation time (s) & $1,319 \pm 9^{\mathrm{b}}$ & $1,428 \pm 35^{\mathrm{ac}}$ & $1,367 \pm 32^{\mathrm{bc}}$ & $1,400 \pm 32^{\mathrm{bc}}$ & $1,417 \pm 12^{\mathrm{ac}}$ & $<0.05$ \\
\hline Curd firmness $\left(\mathrm{a}_{30} ; \mathrm{mm}\right)$ & $24.02 \pm 0.52^{\mathrm{a}}$ & $19.70 \pm 0.77^{\mathrm{bc}}$ & $20.93 \pm 0.75^{\mathrm{ac}}$ & $19.55 \pm 0.82^{\mathrm{b}}$ & $19.62 \pm 0.74^{\mathrm{b}}$ & $<0.01$ \\
\hline Lysine $(\mu \mathrm{g} / \mathrm{mL})$ & $1.60 \pm 0.11^{\mathrm{c}}$ & $1.99 \pm 0.09^{\mathrm{c}}$ & $2.40 \pm 0.09^{\mathrm{b}}$ & $2.80 \pm 0.08^{\mathrm{a}}$ & $2.97 \pm 0.05^{\mathrm{a}}$ & $<0.01$ \\
\hline Arginine $(\mu \mathrm{g} / \mathrm{mL})$ & $2.30 \pm 0.08^{\mathrm{b}}$ & $2.73 \pm 0.06^{\mathrm{a}}$ & $2.82 \pm 0.05^{\mathrm{a}}$ & $3.04 \pm 0.11^{\mathrm{a}}$ & $2.77 \pm 0.18^{\mathrm{a}}$ & $<0.01$ \\
\hline$\beta-\mathrm{CN}(\mathrm{g} / \mathrm{L})$ & $10.22 \pm 0.28^{\mathrm{bcd}}$ & $9.81 \pm 0.29^{\mathrm{bd}}$ & $11.20 \pm 0.12^{\mathrm{a}}$ & $11.12 \pm 0.23^{\mathrm{ac}}$ & $10.87 \pm 0.12^{\mathrm{ad}}$ & $<0.05$ \\
\hline$\beta-\mathrm{LG}-\mathrm{b}(\mathrm{g} / \mathrm{L})$ & $2.25 \pm 0.06^{\mathrm{ac}}$ & $2.13 \pm 0.08^{\mathrm{a}}$ & $2.21 \pm 0.03^{\mathrm{bc}}$ & $2.29 \pm 0.04^{\mathrm{ac}}$ & $2.35 \pm 0.03^{\mathrm{a}}$ & $<0.02$ \\
\hline
\end{tabular}

${ }^{\mathrm{a}-\mathrm{d}}$ Means within a row with different superscripts differ significantly $(P<0.05)$.

${ }^{1}$ Values at each storage temperature represent the least squares means of 12 replicates \pm SEM. 
Table 5. Least squares means analysis of lysine concentration $(\mu \mathrm{g} / \mathrm{mL}$; mean $\pm \mathrm{SE})$ in milk samples stored at different temperatures $\left(2^{\circ} \mathrm{C}, 4^{\circ} \mathrm{C}, 6^{\circ} \mathrm{C}\right)$ and for different durations $(0,24,48,72$, and $96 \mathrm{~h})$

\begin{tabular}{|c|c|c|c|c|c|}
\hline $\begin{array}{l}\text { Temperature } \\
\left({ }^{\circ} \mathrm{C}\right)\end{array}$ & $0 \mathrm{~h}$ & $24 \mathrm{~h}$ & $48 \mathrm{~h}$ & $72 \mathrm{~h}$ & $96 \mathrm{~h}$ \\
\hline 2 & $1.53 \pm 0.18^{\mathrm{bc}}$ & $1.80 \pm 0.16^{\mathrm{bcd}}$ & $2.19 \pm 0.09^{\mathrm{ad}}$ & $2.40 \pm 0.14^{\mathrm{ac}}$ & $2.61 \pm 0.09^{\mathrm{a}, \mathrm{B}}$ \\
\hline 4 & $1.64 \pm 0.18^{\mathrm{d}}$ & $1.88 \pm 0.16^{\mathrm{bd}}$ & $2.39 \pm 0.09^{\mathrm{bc}}$ & $2.99 \pm 0.14^{\mathrm{a}}$ & $2.82 \pm 0.09^{\mathrm{ac}, \mathrm{B}}$ \\
\hline 6 & $1.62 \pm 0.18^{\mathrm{d}}$ & $2.31 \pm 0.16^{\mathrm{bcd}}$ & $2.61 \pm 0.09^{\mathrm{bc}}$ & $3.02 \pm 0.14^{\mathrm{ac}}$ & $3.49 \pm 0.09^{\mathrm{a}, \mathrm{A}}$ \\
\hline
\end{tabular}

${ }^{\mathrm{a}-\mathrm{d}}$ Means within a row with different superscripts differ significantly $(P<0.05)$.

${ }^{\mathrm{A}, \mathrm{B}}$ Means within a column with different superscripts differ significantly $(P<0.05)$.

between 72 and $96 \mathrm{~h}$. The HCT at 0 and $24 \mathrm{~h}$ were different $(P<0.04)$ from those at 48,72 , and $96 \mathrm{~h}$ (Table 4). The limited improvement in HCT between 72 and 96 h was probably due to the addition of fresh milk throughout the sampling period. Davies and Law (1983) and Dalgleish and Law (1989) reported that extensive dissociation of $\beta$-CN occurs during cold storage, with a concomitant increase in the level of $\beta-\mathrm{CN}$ in ultracentrifugal supernatants, which may account for the reduction in HCT. Indeed, Crudden et al. (2005b) reported an increased dissociation of $\beta-\mathrm{CN}$ into the supernatant during storage of skim milk at $5^{\circ} \mathrm{C}$ for 2 and 5 $\mathrm{d}$, as measured using urea-PAGE. This was associated with a reduction in $\mathrm{HCT}$ of $\sim 50 \%$ after $5 \mathrm{~d}$ of storage. The findings of the current study are in agreement with those of Crudden et al. (2005b), although the reduction in $\mathrm{HCT}$ was not as significant in this study, most likely due to the sequential addition of fresh milk.

Between 0 and $24 \mathrm{~h}$, the RCT increased from 1,260 and $1,428 \mathrm{~s}(P<0.03)$ and remained similar thereafter (RCT at $96 \mathrm{~h}=1,416 \mathrm{~s}$; Table 4$)$. Previously, after storing milk from cows classified as producing milk with poor coagulation properties for $72 \mathrm{~h}$ at $4^{\circ} \mathrm{C}$, de Moura Maciel et al. (2015) observed very similar trends in RCT, in agreement with the current study, whereby a longer RCT was observed after $24 \mathrm{~h}$ of storage (increased from $\sim 1,020$ to $1,200 \mathrm{~s}$ ) with no further increase being observed during a further $48 \mathrm{~h}$ of storage. During cold storage, $\beta-\mathrm{CN}$ and colloidal calcium phosphate dissociate from the casein micelle, resulting in changes to the micelle structure that result in poor rennetability (Raynal and Remeuf, 2000). These changes do not occur immediately on cooling but are more or less complete after $24 \mathrm{~h}$ of storage at $4^{\circ} \mathrm{C}$ (Walstra et al., 1999), as observed in the current results.

The $\mathrm{a}_{30}$ decreased between 0 and $96 \mathrm{~h}(P<0.0001$; Table 4). Similar decreases in curd firmness were reported by O'Brien et al. (2001) after 72 and $144 \mathrm{~h}$ of storage of milk at $4^{\circ} \mathrm{C}$. In that study, the deterioration in curd firmness was attributed to a decrease in the relative proportion of casein and a concomitant increase in the loss of protein in the whey fraction during storage because of proteolysis. In the current study, the casein content of milk did not change during storage, but the methodology used to measure the casein contents of milk in this study was unable to differentiate between intact and dissociated $\beta$-CN. The decrease in $\mathrm{a}_{30}$ may thus be linked to the dissociation of $\beta-\mathrm{CN}$ from the casein micelle during refrigerated storage, which can be reversed by heating (Puhan, 1988). A correlation exists between decreases in $\mathrm{a}_{30}$ value and curd yield (Hurtaud et al., 1995; Mara et al., 1998) and this change may be of industrial significance; however, larger studies are needed to evaluate the significance of this effect.

Though statistically significant, the effect of storage time on the $\mathrm{pH}$ of bulk tank milk was minimal (Table 4). Proliferation of lactic acid bacteria during storage increases titratable acidity, with values above $0.18 \%$ being regarded as indicative of spoilage (Lu et al., 2013). In the current study, titratable acidity never exceeded this critical spoilage value. In a similar study in which milk was stored for $5 \mathrm{~d}$ at $5.5^{\circ} \mathrm{C}$, the titratable acidity increased from 0.15 to $0.17 \%$, which was attributed to an increase in microbial population within the storage period (560 to 120,000 cfu/mL; Schmidt et al., 1996). Given that the majority of milk in this study was stored at temperatures below $5.5^{\circ} \mathrm{C}$ for a maximum of $96 \mathrm{~h}$, coupled with the sequential addition of fresh milk throughout the storage period, it is unlikely that sufficient lactic acid bacteria would be present to cause spoilage.

\section{CONCLUSIONS}

Few researchers have examined the effect of storage conditions on milk stored in bulk tanks located on farms. Such studies simulate the conditions experienced on commercial farms. The composition and functional properties of milk differed between mid and late lactation. Milk storage temperature had a negligible effect on gross composition and functional properties of milk and only influenced the concentration of some free amino acids in milk. Between 0 and 96 h, minimal deteriorations in some functional properties were observed, and were most likely due to the dissociation of $\beta-\mathrm{CN}$ from the casein micelle, which can be reversed upon 
pasteurization. Thus, blended milk can be stored for up to $96 \mathrm{~h}$ at temperatures between $2^{\circ} \mathrm{C}$ and $6^{\circ} \mathrm{C}$ with little effect on its composition or functional properties.

\section{REFERENCES}

Albert, C., G. Pohn, K. Lóki, and J. Csapó. 2009. Effect of microorganisms on free amino acid and free D-amino acid contents of various dairy products. Acta Univ. Sapient. Aliment. 2:45-53.

Alichanidis, E., H. H. M. Wrathall, and A. T. Andrews. 1986. Heat stability of plasmin (milk proteinase) and plasminogen. J. Dairy Res. 53:259-269.

Andrews, A. T. 1983. Proteinases in normal bovine milk and their action on the caseins. J. Dairy Res. 50:45-55.

Auldist, M. J., S. Coats, B. J. Sutherland, J. J. Mayes, G. H. McDowell, and G. L. Rogers. 1996. Effects of somatic cell count and stage of lactation on raw milk composition and the yield and quality of Cheddar cheese. J. Dairy Res. 63:269-280.

Barbano, D. M., R. R. Rasmussen, and J. M. Lynch. 1991. Influence of milk somatic cell count and milk age on cheese yield. J. Dairy Sci. 74:369-388.

Barkema, H. W., Y. H. Schukken, T. J. Lam, M. L. Beiboer, H. Wilmink, G. Benedictus, and A. Brand. 1998. Incidence of clinical mastitis in dairy herds grouped in three categories by bulk milk somatic cell counts. J. Dairy Sci. 81:411-419.

Barry, J. G., and W. J. Donnelly. 1980. Casein compositional studies: 1. The composition of casein from Friesian herd milks. J. Dairy Res. 47:71-81.

Bastian, E. D., and R. J. Brown. 1996. Plasmin in milk and dairy products: An update. Int. Dairy J. 6:435-457.

Berry, D. P., B. O'Brien, E. J. O'Callaghan, K. O. Sullivan, and W. J. Meaney. 2006. Temporal trends in bulk tank somatic cell count and total bacterial count in Irish dairy herds during the past decade. J. Dairy Sci. 89:4083-4093.

Crudden, A., D. Afoufa-Bastien, P. F. Fox, G. Brisson, and A. L. Kelly. 2005a. Effect of hydrolysis of casein by plasmin on the heat stability of milk. Int. Dairy J. 15:1017-1025.

Crudden, A., P. Fox, and A. Kelly. 2005b. Factors affecting the hydrolytic action of plasmin in milk. Int. Dairy J. 15:305-313.

Dalgleish, D. G., and A. J. R. Law. 1989. pH-induced dissociation of bovine casein micelles. II. Mineral solubilisation and its relation to casein release. J. Dairy Res. 56:727-735.

Davies, D. T., and A. J. R. Law. 1983. Variation in the protein composition of bovine casein micelles and serum casein in relation to micellar size and milk temperature. J. Dairy Res. 50:67-75.

Davies, D. T., and J. C. D. White. 1966. The stability of milk protein to heat. 1. Subjective measurement of heat stability of milk. J. Dairy Res. 33:67-81.

Davis, T. A., H. V. Nguyen, R. Garcia-Bravo, M. L. Fiorotto, E. M. Jackson, D. S. Lewis, D. R. Lee, and P. J. Reeds. 1994. Amino acid composition of human milk is not unique. J. Nutr. 124:1126-1132.

de Moura Maciel, G., M. Hammershøj, P. D. Frederiksen, J. Sørensen, M. Bakman, N. A. Poulsen, and L. B. Larsen. 2015. Dairy processing and cold storage affect the milk coagulation properties in relation to cheese production. Dairy Sci. Technol. 95:101-114.

Deeth, H. C. 2006. Lipoprotein lipase and lipolysis in milk. Int. Dairy J. $16: 555-562$.

Deeth, H. C., and C. H. Fitzgerald. 1995. Lipolytic enzymes and hydrolytic rancidity in milk and milk products. Pages $247-308$ in Advanced Dairy Chemistry - 2: Lipids. 2nd ed. P. F. Fox, ed. Chapman and Hall, London, UK.

Dickow, J. A., L. B. Larsen, M. Hammershøj, and L. Wiking. 2011. Cooling causes changes in the distribution of lipoprotein lipase and milk fat globule membrane proteins between the skim milk and cream phase. J. Dairy Sci. 94:646-656.

Doolan, I. A., A. B. Nongonierma, K. N. Kilcawley, and M. G. Wilkinson. 2014. Partitioning of starter bacteria and added exogenous enzyme activities between curd and whey during Cheddar cheese manufacture. Int. Dairy J. 34:159-166.
Driessen, F. M. 1989. Inactivation of lipases and proteinases (indigenous and bacterial). Pages 71-93 in Bulletin of the International Dairy Federation 238. International Dairy Federation, Brussels, Belgium.

European Commission. 1992. Annex A Council Directive 92/46/EEC. Health rules for the production and placing on the market of raw milk, heat-treated milk and milk-based products. European Commission, Brussels, Belgium.

Fenlon, D. R., D. N. Logue, J. Gunn, and J. Wilson. 1995. A study of mastitis bacteria and herd management practices to identify their relationship to high somatic cell counts in bulk tank milk. Br. Vet. J. 151:17-25.

Gandolfi, I., G. Palla, L. Delprato, F. Nisco, R. Marchelli, and C. Salvadori. 1992. D-Amino acids in milk as related to heat treatments and bacterial activity. J. Food Sci. 57:377-379.

Guinee, T. P., C. Gorry, D. J. O'Callaghan, B. T. O'Kennedy, N. O'Brien, and M. A. Fenelon. 1997. The effects of composition and some processing treatments on the rennet coagulation properties of milk. Int. J. Dairy Technol. 50:99-106.

Guinee, T. P., B. O'Brien, and E. Mulholland. 2007. The suitability of milk from a spring calved dairy herd during the transition from normal to very late lactation for the manufacture of low-moisture Mozzarella cheese. Int. Dairy J. 17:133-142.

Guinot-Thomas, P., M. Al Ammoury, and F. Laurent. 1995b. Effects of storage conditions on the composition of raw milk. Int. Dairy J. 5:211-223.

Guinot-Thomas, P., M. Ammoury, Y. Le Roux, and F. Laurent. 1995a Study of proteolysis during storage of raw milk at $4^{\circ} \mathrm{C}$ : Effect of plasmin and microbial proteinases. Int. Dairy J. 5:685-697.

Hagnestam-Nielsen, C., U. Emanuelson, B. Berglund, and E. Strandberg. 2009. Relationship between somatic cell count and milk yield in different stages of lactation. J. Dairy Sci. 92:3124-3133.

Hantsis-Zacharov, E., and M. Halpern. 2007. Culturable psychrotrophic bacterial communities in raw milk and their proteolytic and lipolytic traits. Appl. Environ. Microbiol. 73:7162-7168.

Haryani, S., N. Datta, A. J. Elliott, and H. C. Deeth. 2003. Production of proteinases by psychrotrophic bacteria in raw milk stored at low temperature. Aust. J. Dairy Technol. 58:16-20.

Hurtaud, C., H. Rulquin, M. Delaite, and R. Verita. 1995. Prediction of cheese yielding efficiency of individual milk of dairy cows-Correlation with coagulation properties and laboratory cheese yield. Ann. Zootech. 44:395-398.

IDF. 2001. Milk—Determination of Nitrogen Content-Part 4: Block Digestion Method (Semi-micro Rapid Routine Method). Standard 20-3. International Dairy Federation (IDF), Brussels, Belgium.

IDF. 2004a. Milk-Determination of Casein-Nitrogen Content-Part 1: Indirect Method (Reference Method). Standard 29-1. International Dairy Federation (IDF), Brussels, Belgium.

IDF. 2004b. Milk-Determination of Nitrogen Content-Part 3: Block Digestion Method (Semi-micro Rapid Routine Method). Standard 20-3. International Dairy Federation (IDF), Brussels, Belgium.

Kefford, B., M. P. Christian, B. J. Sutherland, J. J. Mayes, and C. Grainger. 1995. Seasonal influences on Cheddar cheese manufacture: Influence of diet quality and stage of lactation. J. Dairy Res. 62:529-537.

Kelly, P. M., M. K. O'Keefe, J. A. Keogh, and J. A. Phelan. 1982. Studies of milk composition and its relationship to some processing criteria. III: Seasonal variation in heat stability of milk. Irish J. Food Sci. Technol. 6:29-38.

Klei, L., J. Yun, A. Sapru, J. Lynch, D. Barbano, P. Sears, and D. Galton. 1998. Effects of milk somatic cell count on Cottage cheese yield and quality. J. Dairy Sci. 81:1205-1213.

Le Bars, D., and J. C. Gripon. 1989. Specificity of plasmin towards bovine alpha $\mathrm{S} 2^{-}$casein. J. Dairy Res. 56:817-821.

Leitner, G., N. Silanikove, S. Jacobi, L. Weisblit, S. Bernstein, and U. Merin. 2008. The influence of storage on the farm and in dairy silos on milk quality for cheese production. Int. Dairy J. 18:109-113.

Lindmark-Månsson, H., R. Fonden, and H. E. Pettersson. 2003. Composition of Swedish dairy milk. Int. Dairy J. 13:409-442. 
Lu, M., Y. Shiau, J. Wong, R. Lin, H. Kravis, T. Blackmon, T. Pakzad, T. Jen, A. Cheng, and J. Chang. 2013. Milk spoilage: Methods and practices of detecting milk quality. Food Nutr. Sci. 4:113-123.

Lucey, J. 1996. Cheesemaking from grass based seasonal milk and problems associated with late-lactation milk. J. Soc. Dairy Technol. 49:59-64.

Ma, Y., C. Ryan, D. M. Barbano, D. M. Galton, M. A. Rudan, and K. J. Boor. 2000. Effects of somatic cell count on quality and shelf-life of pasteurized fluid milk 1. J. Dairy Sci. 83:264-274.

Mara, O., C. Roupie, A. Duff, and A. L. Kelly. 1998. The curd-forming properties of milk as affected by the action of plasmin. Int. Dairy J. 8:807-812.

McSweeney, P. L. H., P. F. Fox, J. A. Lucey, K. N. Jordan, and T. M. Cogan. 1993b. Contribution of the indigenous microflora to the maturation of cheddar cheese. Int. Dairy J. 3:613-634.

McSweeney, P. L. H., N. F. Olson, P. F. Fox, A. Healy, and P. Højrup. 1993a. Proteolytic specificity of plasmin on bovine as1-casein. Food Biotechnol. 7:143-158.

Mounsey, J. S., and B. T. O'Kennedy. 2009. Stability of $\beta$-lactoglobulin/ micellar casein mixtures on heating in simulated milk ultrafiltrate at pH 6.0. Int. J. Dairy Technol. 62:493-499.

Muir, D. D., M. E. Kelly, and J. D. Phillips. 1978. The effect of storage temperature on bacterial growth and lipolysis in raw milk. Int. J. Dairy Technol. 31:203-208.

O'Brien, B., W. J. Meaney, D. McDonagh, and A. Kelly. 2001. Influence of somatic cell count and storage interval on composition and processing characteristics of milk from cows in late lactation. Aust. J. Dairy Technol. 56:213-218.

O'Brien, B., J. J. Murphy, T. Guinee, G. Ryan, and R. Mehra. 1999. Chemical composition and processability of milks from herds with different calving patterns. Accessed Sep. 16, 2015. http://www. teagasc.ie/research/reports/dairyproduction/4349/eopr-4349.pdf.

O'Connell, A., S. McParland, P. L. Ruegg, B. O'Brien, and D. Gleeson. 2015. Seasonal trends in milk quality in Ireland between 2007 and 2011. J. Dairy Sci. 98:3778-3790.

O'Connell, A., P. L. Ruegg, K. Jordan, B. O'Brien, and D. Gleeson. 2016. The effect of storage temperature and duration on the microbial quality of bulk tank milk. J. Dairy Sci. 99:3367-3374.

O'Mahony, J. A., and P. F. Fox. 2013. Milk Proteins: Introduction and Historical Aspects. Pages 43-85 in Advanced Dairy Chemistry. Volume 1A Proteins: Basic Aspects. 4th ed. P. L. H. McSweeney and P. F. Fox ed. Springer, New York, NY.

Ostersen, S., J. Foldager, and J. E. Hermansen. 1997. Effects of stage of lactation, milk protein genotype and body condition at calving on protein composition and renneting properties of bovine milk. J. Dairy Res. 64:207-219.
Phelan, J., A. O'Keeffe, M. Keogh, and P. Kelly. 1982. Studies of milk composition and its relationship to some processing criteria: 1. Seasonal changes in the composition of Irish milk. Irish J. Food Sci. Technol. 6:1-11.

Puhan, Z. 1988. Treatment of milk prior to fermentation, in Fermented Milks-Science and Technology. Pages 66-74 in Bulletin of the International Dairy Federation 227. International Dairy Federation. International Dairy Federation, Brussels, Belgium.

Quinn, N., L. Killen, and F. Buckley. 2006. Modelling fat and protein concentration curves for Irish dairy cows. Ir. J. Agric. Food Res. 45:13-23.

Rassin, D. K., J. A. Sturman, and G. E. Guall. 1978. Taurine and other free amino acids in milk of man and other mammals. Early Hum. Dev. 2:1-13.

Raynal, K., and F. Remeuf. 2000. Effect of storage at $4^{\circ} \mathrm{C}$ on the physicochemical and renneting properties of milk: A comparison of caprine, ovine and bovine milks. J. Dairy Res. 67:199-207.

Rodrigues, A. C. O., D. Z. Caraviello, and P. L. Ruegg. 2005. Management of Wisconsin dairy herds enrolled in milk quality teams. J. Dairy Sci. 88:2660-2671.

SAS Institute. 2011. SAS 9.3 Output Delivery System: User's Guide. SAS Institute Inc., Cary, NC.

Schmidt, K. A., J. Stupar, J. E. Shirley, S. Adapa, and D. Sukup. 1996. Factors affecting titratable acidity in raw milk. Accessed Sep. 16, 2015. http://krex.k-state.edu/dspace/handle/2097/8804.

Schroeder, D. L., S. S. Nielsen, and K. D. Hayes. 2008. The effect of raw milk storage temperature on plasmin activity and plasminogen activation in pasteurized milk. Int. Dairy J. 18:114-119.

Sorhaug, T., and L. Stepaniak. 1997. Psychrotrophs and their enzymes in milk and dairy products: Quality aspects. Trends Food Sci. Technol. 8:35-41.

Ueshima, S., K. Okada, and O. Matsuo. 1996. Stabilization of plasmin by lysine derivatives. Clin. Chim. Acta 245:7-18.

Upton, J., J. Humphreys, P. W. G. Groot Koerkamp, P. French, P. Dillon, and I. J. M. De Boer. 2013. Energy demand on dairy farms in Ireland. J. Dairy Sci. 96:6489-6498.

Walstra, P., T. J. Geurts, A. Noomen, A. Jellema, and M. A. J. S. van Boekel. 1999. Dairy Technology: Principles of Milk Properties and Processes. Marcel Dekker Inc., New York, NY.

White, J. C. D., and D. T. Davies. 1958. The relation between the chemical composition of milk and the stability of the caseinate complex. 1 General introduction, description of samples, methods and chemical composition of samples. J. Dairy Res. 25:236-255.

Wiking, L., M. B. Frøst, L. B. Larsen, and J. H. Nielsen. 2002. Effects of storage conditions on lipolysis, proteolysis and sensory attributes in high quality raw milk. Milchwissenschaft 57:190-194. 